\title{
Conceptualizing Institutional Policies for Students' Academic Success in Cambodian Universities: What Matters for Policy?
}

\author{
Rany Sam ${ }^{1}$, Thongma Souriyavongsa ${ }^{1}$, Ahmad Nurulazam Md Zain ${ }^{2}$, Hazri Jamil ${ }^{1}$, Xiaojuan $\mathrm{Wu}^{1}$ \& Seng \\ Sovath $^{3}$ \\ ${ }^{1}$ School of Educational Studies, Universiti Sains Malaysia, Malaysia \\ ${ }^{2}$ School of Educational Studies and National Higher Education Research Institute, Universiti Sains Malaysia, \\ Penang, Malaysia \\ ${ }^{3}$ Department of Legislation, Cambodian Ministry of Education, Youth, and Sports, Cambodia \\ Correspondence: Rany Sam, School of Educational Studies, Universiti Sains Malaysia, 11800, Penang, Malaysia. \\ Tel: 60-17-506-3234.E-mail: sr11_edu045@student.usm.my
}

Received: February 10, 2013 Accepted: May 23, 2013 Online Published: August 1, 2013

doi:10.5539/ass.v9n10p283 URL: http://dx.doi.org/10.5539/ass.v9n10p283

\begin{abstract}
The Cambodian government aims to promote students' academic success in the country's tertiary education. In order to reach this goal, it is important to explore possible potential factors that determine the educational attainment of Cambodian students. There has been no previous research on students' academic success in Cambodian higher learning institutions, while this topic has been widely researched in the United States and some developed countries since the 1970's. Accordingly, a number of research models have been developed by famous scholars to determine institutional factors which lead to the outcome of better academic performance in post secondary education. Therefore, this paper intends to conceptualize the academic experiences connected to existing institutional policies for contributing to the enhancement of students' academic success in the specific context of Cambodian higher education institutions. In this paper, Astin's theory $(1984,1993,1999)$ and a Tinto's theory $(1975,1993)$ are employed to link the concept of institutional policies and Cambodian students' academic success because they model the relationship between institutional experiences of students, which are deemed to be relevant to the current status of Cambodian educational policies. Based on these concepts, this paper will propose ten variables as predicting factors that influence institutional policies toward students' academic success and will design a conceptual model to elaborate this influence within the Cambodian educational system. Thus, this model to predict students' academic success is proposed as a result of a literature review among the relationships of theoretical model of student input (pre-entry attributes), academic environment (institutional experiences and policies), and students' academic success. Based on these relationships, ten propositions are developed.
\end{abstract}

Keywords: conceptualizing, institutional policies, academic success, Cambodian universities

\section{Introduction}

After 28 turbulent years of civil war (1970-1998), the Royal Government of Cambodia initiated policies to restore its tertiary education system in order to be integrated and competitive at the regional and international levels, especially, in the Association of South East Asian Nations (ASEAN). Cambodian post secondary education has experienced tremendous change as a result of the privatization policies implemented by the Government with the goal to increase access by increasing the number of higher learning institutions throughout the country in 1997 (Chamnan \& Ford, 2004). Consequently, there are 97 higher education institutions in which 38 are public universities and 59 are private universities located in 18 provinces and in the capital. The top ten universities, which include the Royal University of Phnom Penh, the Royal University of Law and Economics, the National University of Management, the University of Health Science, the Cambodian Institute of Technology, the Royal University of Agriculture, the Paññāsāstra University of Cambodia, the University of Cambodia, the Norton University, and the Cambodian Mekong University, are located in the capital of Phnom Penh. This expansion is a positive response to the increasing number of students who graduated from secondary education every year; for example, 114,414 high students have finished their studies in the academic year 2011-2012. The total of tertiary student enrollment is 14 percent (WB, 2011). There are 246,069 undergraduate students currently studying in Cambodian universities (MoEYS, 2012; Sam \& Jamil, 2012a). Nevertheless, the rapid development of higher 
learning institutions and enrolments have impacted on the students' academic success, student perseverance, and employment opportunities because of the limited institutional support service policies and other necessary academic resources. According to UNESCO (2010), the dropout rate of undergraduate students was approximately $26 \%$ during the first year. About $80 \%$ of students, who come from poor families in rural and remote areas, enrolled in the universities in the capital city so that they have to overcome adjustment problems in order to succeed in their tertiary education. Approximately $80.50 \%$ of the Cambodian population live in rural areas, $55 \%$ of them live on the agricultural sector, and 35\% live in poverty (NIS, 2008; WB, 2011).

Additionally, there are critical problems, studied by various educational researchers, that can affect the students' academic experiences and success such as the Government's financial constraints, lack of admission requirements and academic support services, lack of human resources, teaching quality, and research capacity, academic relevance, and autonomy, and academic freedom within universities (DRFC, 2010; Sam \& Jamil, 2012b). As mentioned by Pascarella and Terenzini (2005), students' academic success doesn't only refer to the attainment of a degree or graduation, but it concerns also career success, social and economic status, and quality of life. Not surprisingly, most Cambodian public and private universities are more likely to provide the same academic disciplines in Business Administration, Economics, Law, and Foreign Languages, even though job opportunities in these areas are very limited. In spite of that, Cambodian job markets mostly demand skilled workers who come from the disciplines of Science, Engineering, Information Technology, Mathematics, Agriculture, and Health, which are the country's social needs and development. As a result, graduates' professional skills are less likely to match with market demands and career prospects (Chen, Sok, \& Sok, 2007; Chet, 2009; Noch, 2009; DRFC, 2010).

To resolve such challenges, the Cambodian government is constantly reforming its educational system for the enhancement of students' academic success, and the Government has established many national policies, legal frameworks, and institutions: such as the educational strategic plan 2006-2013, the master plan for research in the education sector 2011-2015, the Accreditation Committee of Cambodia, and Supreme National Council of Cambodia. Moreover, Cambodia has continuously strengthened its institutional policies to sustain their academic supported services for students' retention (Sam et al., 2013). As highlighted by the Cambodian prime minister, governmental policies pay more attention to promoting the quality of education and students' academic success through assuring a balance of educational quality and quantity (Sen, 2011). He further suggested that higher education institutions should establish their institutional policies to strengthen the quality of teaching and learning, curricula and extra-curricular activities, and examination procedures in order to meet the regional and international standards. In order to ensure that the Cambodian institutional policies are operating in conformity with the international academic experiences, the combination of Tinto's student retention model $(1975,1993)$, Astin's Input-Environment-Output model $(1984,1988,1999)$ will be employed as conceptual models to explore potential factors that can contribute to students' academic success. Therefore, the goals of this article are to identify ten variables involved in these factors and to develop the general framework for them. This paper introduces the above mentioned concepts to investigate the relationship between student input and academic success, and to examine the association between campus environment and academic success.

\section{Literature Review and Conceptual Foundation}

This paper focuses on investigating the relationship between educational experiences and students' outcomes in the Cambodian context. Astin's theory $(1984,1993,1999)$ and Tinto's theory $(1975,1993)$ are used to illustrate the institutional and educational experiences of Cambodian students because these theories involve the institutional stakeholders in terms of student engagement in the institutional support services as well as academic development, retention, and graduation rates. Astin's theory of Input-Environment- Output/Outcome (I-E-O) model as captured in Figure 1 is adopted to guide the proposed conceptual model of this study because it reflects a theoretical framework to illustrate the cause and effect between the students' input and the students' outcomes of their educational experiences.

According to Astin's theory of Input-Environment- Output/Outcome (I-E-O) model , input referred to personal characteristics of the student at the time before enrolling in the institutions (Astin, 1993). The highlighted characteristics of input may be family background, marital status, age, gender, race, parental education, housing, high school grades, goal commitment and academic self -concept, social experiences, achievement expectancies, and past experiences. Environment in this context is defined as institutional resources to facilitate the learning atmosphere of the student including various programs, policies, faculties, peers and educational experiences (Astin, 1993, p. 7). The outcome is identified as the students' resultant characteristics such as knowledge, skills, critical thinking, attitudes, values, beliefs, and behaviour after being involved in the academic environment and the student's level of academic success (Astin, 1993, 1999). 
In the same vein, Astin's theory correlates to Tinto's (1975) theoretical model of student's attributes and perseverance which comprises four main elements. The first element refers to pre-entry attributes such as family background (socioeconomic status, parental educational level, and expectation), individual attributes (academic ability, race, and gender), and prior schooling (characteristics of the student's secondary school, and high school academic grades, and social attainments). The second and third elements are considered as the institutional environment which includes both the student's aspirations and the institutional goals, institutional commitments (academicians and faculty interaction, peer group interaction, and curricular involvement), and academic and social integration. The last element is the outcome.

Based on the studies by (Tinto, 1993), a student's perseverance or departure is measured by the degree of academic integration and social integration of the student. Academic integration reflects satisfaction with academic achievements such as earning passing grades and academic progress. Social integration refers to the component of peer to peer interaction, faculty- student interaction, and extracurricular activities. It also refers to how the institution's social environment fits into the student's background, values, and aspirations. Tinto asserted that there are two dimensions of commitment which directly influence persistence or departure behaviour: institutional commitment and personal goal commitment. Institutional commitment is the degree of motivation and academic support services of the university or college that are provided to students. Goal commitment is the degree of a student's commitment or motivation that the student has to persist in their studies to graduation. Tinto proposed that increased levels of academic and social integration and institutional and goal commitments directly influence a student's commitment and the outcome which is the departure decision: graduate, transfer, or drop out. Tinto's (1993) theoretical model of student integration relates to the following components which indicate student persistence in college or university. Thus, the Tinto's theoretical model $(1975,1993)$ illustrates the need to provide academic and social support services in order to promote student retention and academic success in education institutions so that students achieve academic success.

Therefore, this paper adopts the above models, first experienced in the United States context, because they allow us to concentrate on the institutional and educational experiences regarded as academic and non-academic support services which are provided by Cambodian universities. Furthermore, these academic support services relate to the nine-minimum quality assurance standards of the Accreditation Committee of Cambodia that contribute to students' academic success such as (1) mission statement, (2) governing structure, (3) management and planning, (4) curricula and extra-curricular activities, (5) academic staff development, (6) student and student services , (7) learning services, (8) physical plant, (9) information dissemination. Based on the literature review above, the following conceptual model can be used to guide research on institutional policies that contribute to Cambodian students' academic success as shown in Figure 1.

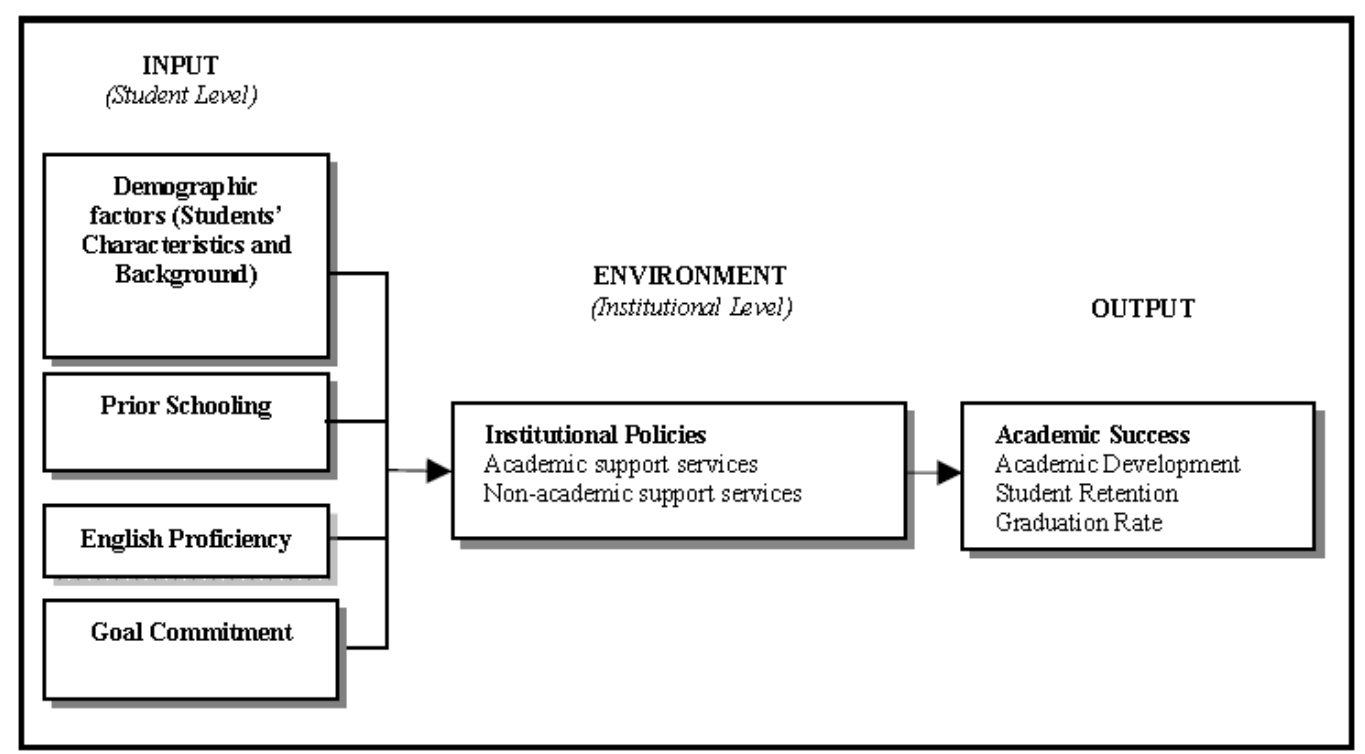

Figure 1. Astin's input-environment- output model $(1984,1993,1999)$ and Tinto's student retention model (1975, 1993) 


\subsection{The Relationship between Student Input and Students' Academic Success}

In this study, student input refers to students' personal characteristics before enrolling in the institutions. It relates to (1) demographic factors, (2) prior schooling, (3) English proficiency, and (4) goal commitment. Hence, the paper will examine the association between the student input and students' academic success as follows:

\subsubsection{Linking Demographic Factor and Stduents' Academic Success}

In this study, demographic factors refers to students' characteristic background, parental educational background, and their social economic status. Parental education and employment background are one of the significant factors that is positively related to students' academic success (McKenzie \& Schweitzer, 2001; Bruinsma \& Jansen, 2007). According to Melby and Conger (1996), family income, parental education, parental involvement and hostility have an influence on the academic experience of students in their secondary and post secondary education. Henry et al. (1993) identified that parental involvement in support, reasoning, punishment, monitoring, and autonomy granting encourage students to successfully navigate their campus life; students who regularly received psychological counselling from their parents, tend to obtain significant skills for their academic success in university.

A study carried out by Jeynes (2002), demonstrated that parents' educational level, occupational status, and income level, which constitute their social economic status, are associated with academic performance. Based on the cultural capital theory students who come from well educated families will obtain success (McMillan \& Western, 2000). It is undeniable that low social economic status negatively impact on academic success because students cannot access much necessary resources for their academic development. In addition, social economic background is one of the major components of educational quality; academic success strongly depends on the social economic status of parents who economically foster their children to get academic achievement (Graetz, 1995; Considine \& Zappala, 2002; Eamon 2005; Jeynes, 2002). Based on the literature above, the authors propose the first proposition.

\section{Proposition 1: Demographic factors will be related to academic success.}

\subsubsection{Linking Prior Schooling and Students' Academic Success}

Prior schooling is defined as the characteristics of the student's high school, his or her academic grades, and social attainments prior to attendance at the college or university. One factor that appears to affect academic success is prior schooling results. Based on the studies of validity of high school grades in predicting student success beyond the first year by Geiser and Santelices (2007), it is found that grade point average (GPA) of high school results is invariably the best predictor of college grades. For instance, one research has investigated how high school grades affect college grades. Researchers have selected 80,000 students as research samples who were admitted to the University of California and observed their four- year college outcomes such as cumulative grade point average (CGPA) and graduation rates in order to find out the linkage of high school record in forecasting a long- term college performance. Based on the findings of this research, high school grades were a strong prediction for a four year college outcomes for all academic disciplines (Geiser \& Studley, 2003). Findings similar to those made by Geiser and Santelics (2007) were confirmed by Anderson, Benjamin and Fuss (1994) whose study on the determinants of academic success and post secondary education found that students who have good academic performance in high school also have better academic performance in college. As highlighted by Geiser and Santelics (2007); Anderson, Benjamin and Fuss (1994), it was undeniable that high school grades are the best predictors of academic performance in the United States.

In addition, prospective college students who have actively engaged in high school activities have an affirmative predictor of a student's predisposition to participate in college; successful involvement in high school activities is associated with the predisposition to academic success in college (Borus, 1993; Hossler \& Gallangher, 1987; Manski \& Wise, 1983). The quality of the high school curriculum and its academic experience impact on students' academic success in post secondary education. That is, students who with quality academic experiences in high school will perform well academically will do in college even though they come from different demographic social economic background (Florida Department of Education 2005; Gladieux \& Swail 1998, Horn \& Kojaku 2001; Martinez \& Klopott 2003; Warburton, Bugarin, \& Nunez 2001). Thus, prior schooling characteristics can be useful predictors of student retention, and the results of these studies could be employed for college admission (Paul, Leslie, \& Jill, 1999). However, it cannot explain all of the various attrition rates of students; yet students prefer to stay in school when they are actively involved in campus programs and feel a sense of community at the institution (Astin, 1993; Tinto, 1993; Naretto, 1995). From the literature above, the authors propose the second proposition. 


\section{Proposition 2: Prior schooling will be related to academic success.}

\subsubsection{Linking English Proficiency and Students' Academic Success}

English proficiency and students' academic success appear to be positively correlated. Most Cambodian universities set English language as an admission requirement for students to enrol in their program. For example, University of Cambodia and Paññāsāstra University of Cambodia required TOEFL scores of at least 500 or IELTS 5.5 for their undergraduate program. Prospective students need to prove their English proficiency prior to entering the university (PUC, 2013; UC, 2013). A number of researchers have investigated how students' language proficiency in English affect their academic achievement in the United States and the United Kingdom (Polyrazli et al. 2002; Swami et al. 2009). According to Polyrazli et al. (2002), English proficiency enables foreign students to succeed in cultural adjustment, social relationships, and in the academic environment at US university. Simarlily, Swimi et al. (2009) found that Malaysian students who have higher English ability easily adjusted in a British university. To succeed in their higher education, Cambodian students need to have higher English proficiency because nearly all the textbooks are written in English. Students who cannot use English, apparently cannot engage well in higher education (Clayton, 2006). Therefore, Cambodian students who want to further their postgraduate degrees in the region and in English speaking countries must have English proficiency because it is the language of international education in the world. That is why all Cambodian Higher Education Institutions are required to provide English courses with qualified teachers and modern language learning facilities (ACC, 2009). From the literature above, the authors propose the third proposition.

\section{Proposition 3: English proficiency will be related to the academic success.}

\subsubsection{Linking Goal Commitment and Students' Academic Success}

Goal commitment is the degree of a student's commitment or motivation to attend college; students' motivation is positively related to college attendance and academic success. Prospective student's personal aspirations have a significant impact on the decision to attend college. Furthermore, students' aspirations and career plans are the most important factors affecting college attendance (Carpenter and Fleishman, 1987; Ariffin, Ahmad, \& Ibrahim, 2008; Jackson, 1987). As a relative research approach, self esteem, goal orientation, self-efficacy and self-regulation, and learning styles of students are also associated with academic success (Feick \& Rhodewalt, 1997; Zhang \& RiCharde, 1997; Niemczyk \& Savenye, 2001). According to Molton, Brown and Lent (1991); Bandura (1997), self-efficacy performs a specific task, and academic self-concept, confidence, assertiveness and positive risk-taking, correlate with academic performance. Students' academic talents can carry them far, but in order to become scholars who can manage their own learning, students need to be self-motivated, engaged and disciplined. In a study carried out by ACT (2008), the strongest predictor of academic success is an academic discipline, which the researcher defines as the "skill component of motivation", reflecting the levels and quality of students' effort in dedicating to schoolwork and the engagement with the new learning environment. Based on the studies by Choy (2002), adults and peers who value academic success can motivate their friends to enhance an academic achievement. A result of this research shows that students are more likely to enrol in college if their peers or friends intend to enrol in college, too. It is four time times more important than their parental encouragement and support (Choy, 2002). From the literature above, the authors propose the fourth proposition.

\section{Proposition 4: Goal commitment will be related to the academic success.}

\subsection{The Relationship between Campus Environment and Students'Academic Success}

In this study, campus environment relates to institutional policies that shape student experiences and outcomes during their studies at university. It is divided into two main support services: academic support services and non academic support services. Academic support services are defined as any service that relates to (1) academic curricular and extracurricular activities, (2) academic staff, (3) physical facilities, and (4) faculty interaction. Non-academic support services are considered as services that related to (5) financial support and scholarship and (6) accommodation and other support services. Therefore, this paper will investigate the linkage between the campus environment and students' academic success.

\subsubsection{Linking Curricular and Extracurricular Activities and Students' Academic Success}

Engagement in curricular and extra-curricular activities correlate with students' academic success; it can be considered as one of the most significant factors to transform students to be successful persons with professional skills and knowledge. In a practical sense, a curricular or study program can vary from one institution to another, but it identifies the different levels of students' academic success. In Cambodian context, the academic program is the third standard that can contribute to students' academic success (ACC, 2009). Curricula should be precise, valuable, and useful for students' job opportunities. Teachers have to explain clearly about course goals and 
objectives to the students in the first session of the course, for instance through a course outline (Mood, 1995). According to Lacke and Neill (2011), the standardized curricula should be designed by universities, and it shall be evaluated by students and teachers to assure that it adapts to students' needs and experiences. Additionally, teachers are required to follow up such curricular so that it benefits the students; the curricula and its contents should encourage and engage students to be actively involved in order to acquire knowledge and skills. Similarly, institutions should regularly update their curricular provision in order to respond to the special needs of students. For example, they should develop new approaches to students relating to workshops and other activities targeting particular aspects of needs including study skills, special courses, etc. (Mantz \& Bernard, 2004). Beside that, extra-curricular activities should be introduced to the students so that they have a chance to put their theories into real practice outside and inside the campus. Students can learn through these experiences how to be self-reliant and mature (Seymour, 1992; Wilde, 2002). From literature above, the authors propose the fifth proposition.

\section{Proposition 5: The academic curriculum and extra-curricular activities enable academic success.}

\subsubsection{Linking Academic Staff and Students' Academic Success}

Lecturers' quality and their experience have a positive association with student achievement (Greenwald et al., 1996; Hanushek, 1996). As mentioned by Mood (1995) and Parr (2005), a good teacher has a principal role to be a facilitator, assessor, participant, and motivator in order to inspire students to be actively involved in the course. The academic staff is listed as in fourth standard among other eight minimum standards for accreditation of higher education (ACC, 2009). Medway and Penny (1994), and Massy (2003) pointed out that good teaching methodology could draw students to be interested in lectures. In a study carried out by Mclnerney (2000), there are nine core stages for teachers in promoting students' academic success as follows: (1) start the lesson with a quick review of previous learning and outline goals, (2) present material in small steps and allow application after each step, (3) Provide clear and detailed instructions and explanations, (4) ask a large number of questions and check for student understanding, (5) guide students in initial phases of learning and application, (6) provide systematic feedback that is task-based, (7) Monitor students as they work, (8) Provide ample time for completing tasks, identify in advance what material/concept might be difficult.

Research on student learning highlights key essentials regarding educational outcomes. These essentials include: (1) importance of intellectual challenge, (2) clear goals, (3) creating a classroom environment where students take responsibility for their own learning, (4) encouraging cooperation between students, (5) concern and respect for students as learners and people, (6) understanding of what students have learnt and what they still need to learn, (7) quality of instruction, (8) quality and quantity of feedback on learning; viewing teaching as a dialogue rather than a transmission process, and (9) understanding of teaching as a process of enabling learners, rather than a set of recipes (Ramsden, 2005; Walberg, 1981; Walberg, 1984). From the literature above, the authors propose the sixth proposition.

\section{Proposition 6: The quality of academic staff enables students' academic success.}

\subsubsection{Linking Physical Facilities and Students' Academic Success}

The sufficient physical facilities, which include libraries, textbooks, learning and teaching materials, are critical factors to facilitate students toward academic success (Harmon \& Wales, 1999; Mavondo et al., 2000). Library services and resources are considered as one of the minimum standards (seventh standard) needed to ensure educational quality and to facilitate students' learning process to help them succeed (ACC, 2009). Moreover, library services have a positive impact on students' academic success including learning, persistence, retention, faculty research productivity, and student job success. For instance, libraries must equipped with new teaching technologies and new electronic information sources including databases, up-to-date textbooks, periodicals, journals, advanced multimedia resources, high-speed Internet access, liquid crystal display projectors (LCD projectors), computer labs, visual and audio equipment to facilitate student learning (Heyneman, 2001, p. 348). According to Belanger and Jordan (2000), reliable facilities and equipments must accessible to students, otherwise it can affect their learning environment. From the literature above, the authors propose the seventh proposition.

\section{Proposition 7: Sufficient modern facilities enable students'academic success.}

\subsubsection{Linking Effective Faculty Interaction and Students' Academic Success}

One of the most significant factors that helps students to achieve academic success is the student faculty interaction. There are three popular theories about the interaction between students and the faculty in promoting student success in college. These three theories are Alexander Astin's Theory of Student Involvement, Vincent 
Tinto's Theory of Student's Persistence or Departure, and Robert Pace's College Impress Model. Astin's theory of student involvement is based on his longitudinal study of college student persistence (Astin, 1984). This study has shown that student involvement contributed to their persistence in college. Conversely, a lack of involvement leads to students' departure from college. Astin pointed out that, "Quite simply, student involvement refers to the amount of physical and psychological energy that the student devotes to the academic experience" (Astin, 1984, p. 297). Similarly, student's persistence is evaluated by the degree of academic integration and social integration of the student. Academic integration regards to academic satisfaction or achievements consists of earning passing grades and academic progress. Most importantly, social integration refers to peer-to-peer interaction, faculty-student interaction, and extracurricular activities (Tinto, 1993). In other words, Pace (1984) asserts that academic success in college is the result of the college environment and the students' effort themselves; he suggests that colleges are responsible for establishing a satisfactory environment for student learning and development, but students themselves have to dedicate their effort and time in college activities.

In addition, according to the World Declaration on Higher Education (1998), teachers and students must implement a workable interactive network involving each other in order to enhance their academic performance, in particular students with their college either local or international levels. Students should be encouraged to learn some social skills such as how to communicate, socialize, and imitate to others; good relationships between the lecturers and their students are a significant factor to help them in academic achievement within the campus environment (Brophy, 1987; Aldridge \& Rowley, 1998). Teachers will develop a better understanding of student learning, knowledge, competence, and willingness in the classroom if they have effectively communicated with their students (Chickering \& Gamson, 1987; Daniels \& Arapostathis, 2005; Konidari \& Abernot, 2006; McGregor, 2007). Based on the Principles of Good Practice in Undergraduate Education, Chickering and Gamson (1987) presented seven effective educational practices, which include student-faculty contact, cooperation among students, active learning, prompt feedback, time on task, high expectations, and respect for diverse talents and ways of learning, which all directly impact on student learning and the quality of their academic performance. From the literature above the authors propose the eighth proposition.

\section{Proposition 8: Effective faculty interaction enables students'academic success}

\subsubsection{Linking Financial Services and Scholarship and Students' Academic Success}

Another significant dimension of academic success is financial support or scholarship. Financial difficulty is a major stress factor affecting many of the students. Chickering and Gamson (1987) suggested that the university must have sufficient funds to offer financial aid to students in order to support their educational and research activities. Based on a report of the Norwegian Ministry of Foreign Affairs (2002), a budget should be allocated to students in strengthening their academic commitment and motivation within studying and researching activities. The funds also should be granted to faculty members and staff, building renovation, and modernized facilities. The sources of funds mainly come from government funding, tuition fees, public donations, and research fees. For instance, France, the UK, Malaysia and Singapore used 18 percent, 22 per cent, 32 per cent and 35 per cent respectively of their government budgets for higher education (Heyneman, 2001). In Cambodia, financial services and scholarships are part of student and student service stipulated in the fifth standard for accreditation of higher education institution that can contribute to students' academic success (ACC, 2009). The provisions of scholarships and financial supports are based on the following criteria: (1) for outstanding or talented students, (2) for deserving students who are not able to afford paying fees for their higher education, (3) for students who are studying in prioritized fields or specializations for society's needs as determined by the Royal Government of Cambodia, and (5) scholarships in response to the policies of the country's leaders. These scholarship awards are based on the proportion of gender, geographic location, and ethnic groups in Cambodia (ACC, 2009; RGC, 2003). From the literature above, the authors propose the ninth proposition.

\section{Proposition 9: Financial service and scholarship enable students'academic success}

\subsubsection{Linking Accommodation Services and Students' Academic Success}

Providing student accommodation or housing in the university campus is considered as a vital support service to facilitate students' academic and non-academic activities. In a practical sense, good universities have an obligation to provide their students a comfortable and safe residence. Accommodation service, which is a part of student and student services, is stipulated in the minimum standard for the Accreditation of Higher Education Institutions in Cambodia. It states that higher learning institutions have to provide good services to their students including accommodation, food services, first aid, security, and other necessary services (ACC, 2009; RGC, 2003). In other words, staying in university campuses is one of the most significant factors to retain students, particularly first year students in college or university. Students who live on campus can persist and move more 
easily to second year when compared with students who live outside the campus. (Jenniefer, 2004; Kenty, 1997). Furthermore, students who stay in university accommodation or residential halls actively participate in university activities and experiences because they have sufficient times to interact with their friends, administrators, and faculty members (Astin, 1999). From the literature above, the authors propose the tenth proposition.

\section{Proposition 10: accommodation services enable students'academic success.}

\section{Proposed Research Model}

With the above literature review, a research model is proposed as shown in Figure 2 for this study.

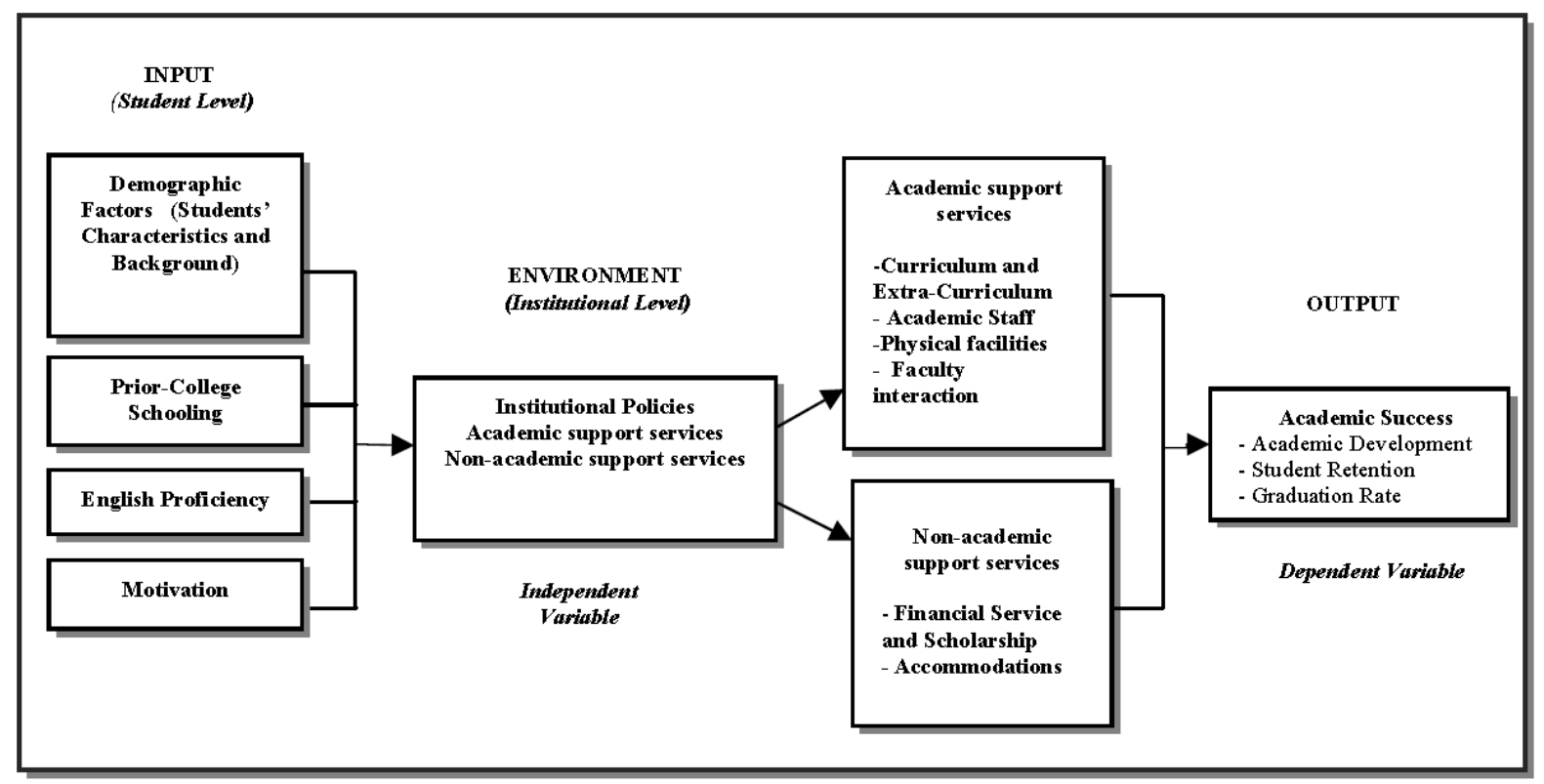

Figure 2. The conceptual model of research

\section{Conclusion}

The goal of this review paper is to explore the potential variables to develop a framework of institutional policies to support the needs of students for the enhancement of their academic success and educational quality as well. This paper also provides a review of previous studies and theories that can be applied to students' academic success in the Cambodian context. Based on the result of a literature review, ten potential factors are correlated with students' academic success including demographic factor, prior schooling factor, English proficiency, goal commitment, academic curriculum and extra-curricular activities, quality of academic staff, sufficient modern facilities, effective faculty interaction, financial services and scholarship, and accommodation services. In other words, this conceptual framework only focuses particularly on institutional policies which are concerned with academic support services that can increase students' retention and academic achievement in Cambodia. However, it seems possible that the academic success concept will differ from one country to another country because of various educational, economic and cultural backgrounds. Ultimately, the proposed research model will guide the researcher to look at the experiences of other countries and add some variables for future empirical investigations.

\section{Acknowledgements}

An earlier version of this paper was presented at the 2012 National Colloquium of Postgraduate Research in Education at the School of Educational Studies of the Universiti Sains Malaysia (USM), during June 6-7, 2012. The main author gratefully acknowledges the support for this study provided by the USM PhD Fellowship Scheme of the Institute of Postgraduate Studies (IPS) at the Universiti Sains Malaysia (USM), Malaysia. The authors would like to thank Professor Dr. Roshada Hashim, Dean of the Institute of Postgraduate Studies and Professor Dr. Abdul Rashid Mohamed, Dean of School of Educational Studies of the Universiti Sains Malaysia for their generous support and kind motivation. Last but not the least, the authors would like to thank Fr. Ashley Evans and Sr. Margaret for their English proofreading and editing.

\section{References}

ACC. (2009). Minimum Standards for Accredition of Higher Education Institutions. Phnom Penh: Accreditation Committee of Cambodia (ACC). Retrieved January 3, 2013, from 
http://www.acc.gov.kh/index.php?option=com_content\&view=article\&id=46\&Itemid=53

ACT. (2008). The forgotten middle: Ensuring that all students are on target for college and career readiness before high school. Iowa City, IA.

Aldridge, S., \& Rowley, J. (1998). Measuring customer satisfaction in higher education. Quality Assurance in Education, 6(4), 197-204. http://dx.doi.org/10.1108/09684889810242182

Anderson, G., Benjamin, D., \& Fuss, M. (1994). Determinants of success in university introductory economics courses. Journal of Economic Education, (spring), 25.

Ariffin, A. A., Ahmad, A. H., Ahmad, M. S., \& Ibrahim, M. A. (2008). Determining decision-making styles and demographic differences in selecting higher education services among Malaysian. International Journal of Business and Society, 9(1), 1-18.

Astin, A. W. (1984). Student Involvement: A Developmental Theory for Higher Education. Journal of College Student Personnel, 25(4), 297-308.

Astin, A. W. (1993). What Matters in College? Four Critical Years Revisited (1st ed.). San Francisco: Jossey-Bass.

Astin, A. W. (1999). Student Involvement: A Developmental Theory for Higher Education. Journal of College Student Development, 40(5), 518-529.

Bailey, T., Jenkins, D., \& Leinbach, T. (2005). Graduation Rates, Student Goals, and Measuring Community College Effectiveness (CCRC Brief Number 28). New York: Columbia University, Community College Research Center.

Bandura, A. (1997). Self-efficacy: The Exercise of Control. New York: Freeman.

Belanger, F., \& Jordan, D. H. (2000). Evaluation and Implementation of Distance Learning: Technologies, Tools and Techniques. Idea Publishing Group, Hershey, PA.

Bensimon, E. M. (2007). Presidential address: The underestimated significance of practitioner knowledge in the scholarship on student success. The Review of Higher Education, 30(4), 441-469. http://dx.doi.org/10.1353/rhe.2007.0032

Borus, M. E. (1993). Factors associated with college attendance of high school seniors. Economics of Education Review, 3(3), 169-176. http://dx.doi.org/10.1016/0272-7757(84)90029-3

Brophy, J. (1987). Synthesis of research on strategies for motivating students to learn. Education Leadership, 45(2), 40-48.

Bruinsma, M., \& Jansen, E. (2007). Educational productivity in higher education: An examination of part of the Walberg educational productivity model. School Effectiveness and School Improvement, 18(1), 45-65. http://dx.doi.org/10.1080/09243450600797711

Carpenter, P. G., \& Fleishman, J. A. (1987). Linking intentions and behaviour: Australian students' college plans and college attendance. American Educational Research Journal, 24(1), 70-105. http://dx.doi.org/10.3102/00028312024001079

Chamnan, P., \& Ford, D. (2004). Cambodian Higher Education: Mixed Visions. In P. G. A. A. T. Umakoshi (Ed.), Asian Universities: Historical Perspectives and Contemporary Challenges (pp. 333-362). Baltimore and London: The Johns Hopkins University Press.

Chen, C. Y., Sok, P., \& Sok, K. (2007). Benchmarking Potential Factors Leading to Educational Quality in Cambodia. Quality Assurance in Education, 15(2), 128-148. http://dx.doi.org/10.1108/09684880710748901

Chet, C. (2009). Higher Education in Cambodia. In Y. H. A. Y. K. (Ed.), The Political Economy of Educational Reforms and Capacity Development in Southeast Asia (pp. 153-165). Springer Science Business Media B.V.

Chickering, W. A., \& Gamson, F. Z. (1987). Seven principles for good practice in undergraduate education. AAHE Bulletin, p.3.

Choy, S. (2002). Access and Persistence: Findings from 10 Years of Longitudinal Research on Students. American Council on Education.

Clayton, T. (2006). The Assistance Context for Language Choice: Education (Cambodia). Language Choice in a Nation under Transition: English Language Spread in Cambodia. USA: Springers, (Chapter 5).

Considine, G., \& Zappala, G. (2002). Influence of social and economic disadvantage in the academic performance of school students in Australia. Journal of Sociology, 38, 129-148. Retrieved August 16, 2007, from http://jos.sagepub.com http://dx.doi.org/10.1177/144078302128756543

Daniels, E., \& Arapostathis, M. (2005). What do they really want? Student voices and motivation research. Urban Education, 40(1), 34-59. http://dx.doi.org/10.1177/0042085904270421

Dowd et al. (2006). Transfer access to elite colleges and universities in the United States: Threading the needle 
of the American dream. Lansdowne, VA: Jack Kent Cooke Foundation.

DRFC. (2010). Scoping Study: Research Capacities of Cambodia's Universities. Phnom Penh: The Development Research Forum in Cambodia.

Eamon, M. K. (2005). Social demographic, school, neighborhood, and parenting influences on academic achievement of Latino young adolescents. Journal of Youth and Adolescence, 34(2), 163-175. http://dx.doi.org/10.1007/s10964-005-3214-x

Engle, J., \& O'Brien, C. (2007). Demography is not destiny: Increasing the graduation rates of low-income college students at large public universities. Washington, DC: The Pell Institute for the Study of Opportunity in Higher Education.

Feick, D., \& Rhodewalt, F. (1997). The double-edged sword of self-handicapping: Discounting, augmentation, and the protection and enhancement of self-esteem. Motivation and Emotion, 21(2), 147-163. http://dx.doi.org/10.1023/A:1024434600296

Florida Department of Education. (2005, March). Post secondary Success Begins with High School Preparation. Tallahassee, FL: Florida Department of Education.

Geiser, S., \& Santelices, V. M. (2007). Validity of high school grades in predicting student success beyond the $\begin{array}{lllll}\text { freshman } \quad \text { year. } & \text { Retrieved } & \text { February 2012, from }\end{array}$ http://cshe.berkeley.edu/publications/docs/ROPS.GEISER_SAT_6.12.07.pdf

Gladieux, L. E., \& Swail, W. S. (1998). Financial Aid is not Enough: Improving the Odds of College Success. College Board Review, (185), 16-21, 30-32.

Graetz, B. (1995). Socioeconomic Status in Education Research and Policy. In J. Ainley, B. Graetz, M. Long, \& M. Batten (Eds.), Social economic Status and School Education. Canberra: DEET/ACER.

Greenwald, R., Hedges, L., \& Laine, R. (1996). The effect of school resources on student achievement. Review of Educational Research, 66(3), 361-396. http://dx.doi.org/10.3102/00346543066003361

Hanushek, E. A. (1996). A more complete picture of school resource policies. Review of Educational Research, 66(3), 397-409. http://dx.doi.org/10.3102/00346543066003397

Harmon, H. A., \& Wales, B. A. (1999). International and domestic students' perception of library personnel and resources. Journal of Teaching in International Business, 10(3), 129-148. http://dx.doi.org/10.1300/J066v10n03_09

Henry, J., Martinko, M., \& Pierce, M. (1993). Attributional style as a predictor of success in a first computer science course. Computers in Human Behavior, 9(4), 341-352. http://dx.doi.org/10.1016/0747-5632(93)90027-P

Heyneman, S. (2001). The growing international market for education goods and services. International Journal of Education Development, 21(4), 345-361. http://dx.doi.org/10.1016/S0738-0593(00)00056-0

Horn, L. J., \& Kojaku, L. K. (2001). High School Academic Curriculum and the Persistence Path through College: Persistence and Transfer Behavior of Undergraduates 3 Years after Entering 4Year Institutions. Education Statistics Quarterly, 3(3), 65-72.

Hossler, D., \& Gallagher, K. (1987). Studying student college choice: A three-phase model and the implications for policy makers. College and University, 62(3), 207-221.

Jackson, G. A. (1987). Financial aid and student enrolment. Journal of Higher Education, 49(6), 548-574. http://dx.doi.org/10.2307/1981139

Jenniefer, C., \& Upgraft, M. (2004). The Key to First-Year Student Persistence. In N. John, L. Upcraft, \& B. Betsy (Eds.), Challenging and Supporting the First Year Student: A Handbook for improving the First Year of College United States. Jossey Bass.

Jeynes, W. H. (2002). Examining the effects of parental absence on the academic achievement of adolescents: the challenge of controlling for family income. Journal of family and Economic Issues, 23(2). http://dx.doi.org/10.1023/A:1015790701554

Kenty, J. (1997). Knowing your students better: A key to involving first-year students. The CRLT Occasional Paper 9.

Konidari, V., \& Abernot, Y. (2006). From TQM to learning organization: another way for quality management in educational institutions. International Journal of Quality \& Reliability Management, 23(1), 8-26. http://dx.doi.org/10.1108/02656710610637523

Leckey, J., \& Neill, N. (2001). Quantifying quality: the importance of student feedback. Quality in Higher Education, 7(1), 19-32. http://dx.doi.org/10.1080/13538320120045058

Manski, C., \& Wise, D. (1983). College Choice in America. Cambridge, MA: Harvard University Press.

Mantz, Y., \& Bernard, L. (2004). Retention and Student Success in Higher Education. Society for Research on 
Higher Education \& Open University Press: UK.

Martinez, M., \& Klopott, S. (2003). Improving College Access for Minority, Low-Income, and First Generation Students. Boston: Pathways to College Network.

Massy, F. W. (2003). Auditing higher education to improve quality. The Chronicle Review, 49(41), B16.

Mavondo, F., Zaman, M., \& Abubakar, B. (2000). Student satisfaction with tertiary institutions and recommending it to prospective students. Paper presented at the Australia, New Zealand Management Academy Conference 2000: Visionary Marketing for the 21st Century: Facing the Challenge.

McGregor, A. (2007). Academic success, clinical failure: Struggling practices of a failing student. Journal of Nursing Education, 46(11), 504-515.

McInerney, D. (2000). Helping kids achieve their best. Sydney: Allen \& Unwin. Retrieved from http://www.det.act.gov.au/_data/assets/pdf_file/0005/17798/Ed_Outcomes_Boys.pd

McKenzie, K., \& Schweitzer, R. (2001). Who succeeds at university? Factors predicting academic performance in first year Australian university students. Higher Education Research and Development, 20(1), 21-33. http://dx.doi.org/10.1080/07924360120043621

McMillan, J., \& Western, J. (2000, Springer). Measurement of Social-Economic Status of Australian Higher Education Students. Higher Education, 39(2). http://dx.doi.org/10.1023/A:1003943824357

Medway, J., \& Penny, R. (1994). Factors affecting successful completion: the Isle of Wight College. The Further Education Unit, unpublished report.

Melby, J. N., \& Conger, R. D. (1996). Parental behaviours and adolescent academic performance: A longitudinal analysis. Journal of Research on Adolescence, 6(1), 113-137.

MoEYS. (2012). Annual Report on Education, Youth, and Sport in academic year 2011-2012. Phnom Penh, Cambodia.

Mood, T. A. (1995). Distance Education: An Annotated Bibliography. Libraries Unlimited, Englewood, CO.

Multon, K. D., Brown, S. D., \& Lent, R. W. (1991). Relation of self-efficacy beliefs to academic outcomes: A meta analytic investigation. Journal of Counselling Psychology, 38, 30-38. http://dx.doi.org/10.1037/0022-0167.38.1.30

Naretto, J. A. (1995). Adult student retention: The influence of internal and external communities. NASPA Journal, 32, 90-97.

Niemczyk, M. C., \& Savenye, W. C. (2001). The relationship of student motivation and self-regulated learning strategies to performance in an undergraduate computer literacy course. Proceedings of the 24 the National Convention of the Association for Educational Communications and Technology, 312322.

NIS. (2008). General Census of Cambodian in 2008. Phnom Penh: National Institute of Statistics of the Ministry of Planing, Cambodia.

Noch, C. (2009). Higher Education and Unemployment of the Educated in Cambodia. Master thesis, The International Institute for Educational Planning (IIEP), UNICEF, Paris.

Norwegian Ministry of Foreign Affairs. (2002). Do your duty-Demand your rights. Report No.27 by Norwegian Government to the Storing (2000-2001). Retrieved January 2, 2013, from http://odin.dep.no.ud/eglish/doc/white_paper/03141-040002/ind-bn.html

Pace, R. (1984). Measuring the quality of college student experiences. An account of the development and use of the College Student Experiences Questionnaire. Los Angeles, CA: University of California, Graduate School of Education, Higher Education Research Institute. (ERIC Document Reproduction Service No. ED $255099)$.

Parr, M. (2005). Knowledge is not enough. Paper presented at the EGSS Conference, 6 November.

Pascarella, E., \& Terenzini, P. (2005). How college affects students: A third decade of research. San Francisco, CA: Jossey Bass.

Paul A., Murtaugh, L. D. B., \& Schuster, J. (1999). Predicting the retention of university students. Research in Higher Education, 40(3).

Poyrazli, S., McPherson, R., Arbona, C., Pisecco, S., \& Nora, A. (2002). Relation between assertiveness, academic self-efficacy, and psychosocial adjustment among international graduate students. Journal of College Student Development, 43(5), 632-642.

PUC. (2013). Admission Requirements for Undergraduate Program. Paññāsāstra University of Cambodia (PUC). Retrieved January 17, 2013, from http://www.puc.edu.kh/admission/admission_requirements_for_undergraduate.html

Ramsden, P. (2005). Using Research on Student Learning to Enhance Educational Quality, Deliberations. 
Retrieved

January

10 ,

2013,

from

http://www.londonmet.ac.uk/deliberations/ocsld-publications/isltpramsden.cfm

RGC. (2003). Royal Degree No. NS/RKT/303/129 dated on March 31, 2003 on the Accreditation of Education Quality in Higher Education Phnom Penh: The Council of Ministers, Cambodia.

Sam, R., Souriyawongsa, T., Zain, A. N. M., \& Hazril, J. (2013). Investigating the Institutional Policies that contribute toward the Students' Academic Success in a Cambodian University. International Journal of Humanities and Social Science, 3(1), 113-124.

Sam, R., Zain, A. N. M., \& Jamil, H. (2012a). Cambodia's Higher Education Development in Historical Perspectives (1863-2012). International Journal of Learning and Development, 2(2), 224-241. http://dx.doi.org/10.5296/ijld.v2i2.1670

Sam, R., Zain, A. N. M., \& Jamil, H. (2012b). Establishment of Institutional Policies for Enhancing Education Quality in Cambodian Universities. International Journal of Higher Education, 1(1), 112-127. http://dx.doi.org/10.5430/ijhe.v1n1p112

Seymour, T. D. (1992). On Q, Causing Quality in Higher Education. The American Council on Higher Education: Macmillan Publishing Company, Riverside, NJ.

Stajkovic, A. D., \& Luthans, F. (1998). Self-efficacy and work-related performances: A meta-analysis. Psychological Bulletin, 124, 240-261. http://dx.doi.org/10.1037/0033-2909.124.2.240

Swami, V., Arteche, A., Chamorro, T., \& Furham, A. (2009). Sociocultural adjustment among sojourning Malaysian students in Britain: A replication and path analytic extension. Social Psychiatry and Psychiatric Epidemiology.

Tinto, V. (1975). Dropout in higher education: A Review and Theoretical synthesis of recent research. Review of Educational Research, 45(1), 89-125. http://dx.doi.org/10.3102/00346543045001089

Tinto, V. (1993). Leaving College: Rethinking the Causes and Cures of Student Attrition. Chicago: The University of Chicago Press.

Tinto, V., \& Pusser, B. (2005). Moving from theory to action: Building a model of institutional action for student success. Washington, DC: National Postsecondary Education Cooperative. June 2006 draft available at http://nces.ed.gov/npec/pdf/Tinto_Pusser_Report.pdf. Transcripts (NCES 2005-171). U.S. Department of Education. Washington, DC: U.S. Government Printing Office.

UC. (2013). General Admission Requirements. University of Cambodia (PUC). Retrieved January 17, 2013, from http://www.uc.edu.kh/ucs/academic/4/14/

UNESCO. (2010). Education System Profile. Retrieved January 10, 2013, from http://www.unescobkk.org/education/resources/country-profiles/cambodia/basic-education/

Walberg, H. J. (1981). A psychological theory of educational productivity. In F. Farley, \& N. Gordon (Eds.), Psychology and Education. McCutchan, Berkeley, CA.

Walberg, H. J. (1984). Improving the productivity of America's schools. Educational Leadership, 41(8), 19-27.

Warburton, E. C., Bugarin, R., \& Nuñez, A. M. (2001). Bridging the Gap: Academic Preparation and Postsecondary Success of First-Generation Students. Retrieved January 10, 2013, from http://techwebsrv.atu.edu/ir/docs/retention-info/retention-other/Postsecondary_Education.pdf

WB. (2011a). School enrollment in Cambodian tertiary education. Retrieved January 10, 2013, from http://data.worldbank.org/indicator/SE.TER.ENRR

WB. (2011b). GDP per capita (current US\$ in Cambodia). Retrieved November 28, 2012, from http://www.data.worldbank.org/indicator/NY.GDP.PCAP.CD

Wilde, J. (2002). The Relationship between Frustration Intolerance and Academic Achievement in College. International Journal of Higher Education, 1(2), 1-8. http://dx.doi.org/10.5430/ijhe.v1n2p1

World Declaration on Higher Education. (1998). Higher education in the twenty-first century: vision and action. Paper presented at World Conference on Higher Education, Paris.

Zhang, Z., \& RiCharde, R. (1997). Learning-thinking style inventory: LISREL and multivariate analyses. Paper presented at the Annual Meeting of the American Educational Research Association. (ERIC Document Reproduction Service No. ED410264).

\section{Copyrights}

Copyright for this article is retained by the author(s), with first publication rights granted to the journal.

This is an open-access article distributed under the terms and conditions of the Creative Commons Attribution license (http://creativecommons.org/licenses/by/3.0/). 